\title{
619 手指有限要素モデルの構築と骨折を考慮した衝撃シミュレーション
}

\section{Finite Element Modeling of Human Finger and Impact Simulation Considering Bone Fracture}

$\bigcirc$
神谷 誠治（東工大）
Hyung-Yun CHOI (Hongik University)
渡邊 竜司（パナソニック電工解析センター）

\author{
正 Jonas A. PRAMUDITA（東工大） \\ 正 宇治橋 貞幸 (東工大) \\ 中村 俊康（慶応大）
}

Seiji KAMIYA, Tokyo Institute of Technology, 2-12-1, Oh-okayama, Meguro-ku, Tokyo Jonas A.PRAMUDITA, Tokyo Institute of Technology, 2-12-1, Oh-okayama, Meguro-ku, Tokyo Hyung-Yun CHOI, Hongik University, 72-1, Sangsu-dong, Mapo-gu, Seoul, 121-791, Korea Sadayuki UJIHASHI, Tokyo Institute of Technology, 2-12-1, Oh-okayama, Meguro-ku, Tokyo Ryoji WATANABE, Panasonic Electric Works Analysis Center, 1048, Kadoma, Kadoma-shi, Osaka Toshiyasu Nakamura, Keio University School of Medicine, 35, Shinanomachi, Shinjyuku-ku, Tokyo

In this study, finger bone fracture simulation method due to pinching was developed. Finger finite element (FE) model was created from CT images of a Japanese male. Material properties of the model were taken from data published previously. In order to realistically represent bone fracture patterns under various loading, EWK rupture model in PAM-CRASH was utilized. The EWK rupture model parameters were determined by comparing the finger model response to reported fracture patterns at long bone under tension, compression, torsion and bending loadings. Finger pinch simulations were conducted under three different conditions including different impactor position and impact direction. Possibility of predicting finger bone fracture patterns from impact conditions using the finger FE model was shown.

Key Words: Biomechanics, Finger injury, EWK rupture model, Bone fracture pattern, Finite element simulation

\section{A 1. 研究目的}

本研究では, 手指有限要素モデルを構築し，そのモデル に骨折を表現できる破壊モデルを導入することにより様々 な衝撃条件下における骨折を予測できる衝撃シミュレーシ ヨン手法を構築することを目的とした。

\section{A 2. 手指有限要素モデルの構築}

日本人標準体型の男性 1 名の CT 画像から指骨とその周 りの軟組織の外形状を抽出し, Fig.A1のようにポリゴンモ デルを作成した．そして，このポリゴンモデルからサーフ エスモデルを作成し，要素分割を行うことにより，手指有 限要素モデルを構築した，本研究では，指挟みによる骨折 傷害を対象としているため，各関節については簡易的にモ デル化することにした.骨モデルは皮質骨と海面骨に分け， 皮下軟組織モデルの表面に皮膚モデルを作成した。各部位 の材料特性については先行研究の值を参考にした。

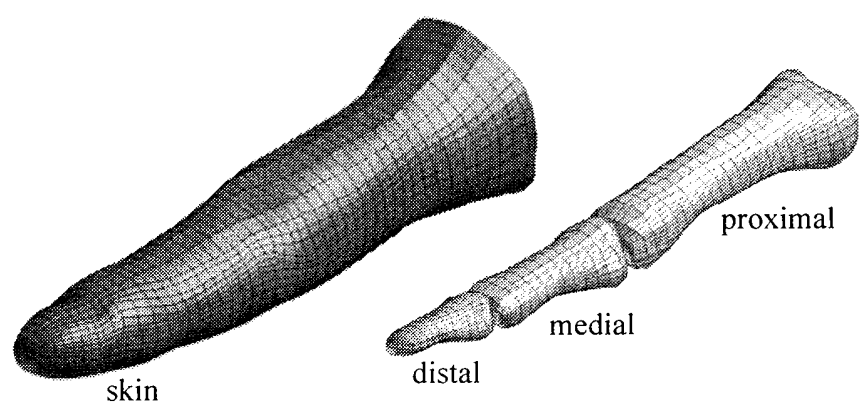

Fig.Al Finger FE model

\section{A 3. 骨折を考虑したシミュレーション}

骨折を予測するためにPAM-CRASH (ESI 社)のEWK 破壊 モデルを用いた．EWK 破壊モデルのパラメータを変更し ながら中節骨の引張, 圧縮, ねじり, 曲げのシミュレーシ ヨンを行った. シミュレーション結果を先行研究で報告さ れた長骨の骨折モードとおおむね一致させることができた． このように同定したパラメータを用いて指挟みの事故を 模擬した衝撃シミュレーションを行った。このシミュレー ションでは, Fig.A2 に示すように一定エネルギーをもった インパクターを指に衝突させた。また，インパクターの位 置を変化させたシミュレーションも行い, シミュレーショ ン結果の比較を行った。その結果, 衝突条件の違いによる 骨折モードの違いを表現することができた. また, 同じ運 動エネルギーをもったインパクターを衝突させても，イン パクターと支持部との位置関係によっては骨折の程度が異 なる可能性があることを示した。

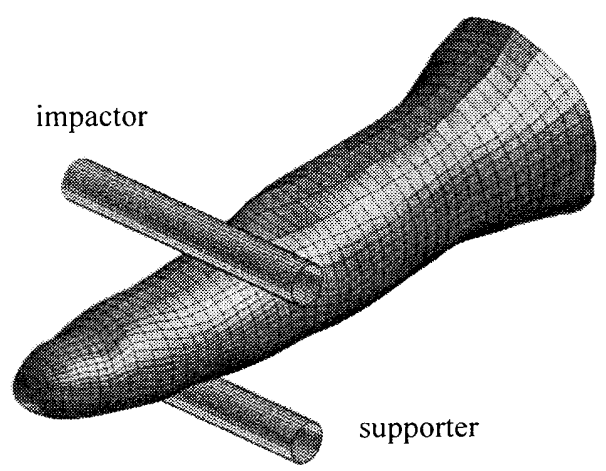

Fig.A2 Finger pinch simulation 


\section{1. 緒論}

日常生活の中で手指は大きな役割を果たしている。しか し，仕事や家事などの日常生活における様々な事故により 指骨の骨折, 軟組織の裂傷, 関節の損傷などの様々な手指 傷害が発生し, 手指の機能を低下させる可能性が高い. 最 近では，折りたたみベビ一カ一や自動車のドアなどの日常 品による指はさみ事故が頻発している(1)(2)ため, 手指傷害 は大きな問題であると認識されるようになり，より高い安 全性を有する製品が求められている.

そこで，手指傷害に対する製品の安全性を評価できる手 法が求められているが，実際の人間の指での評価試験は困 難である。従来，人体傷害に関する研究では，屍体を用い た実験, 物理モデルによる実験, 動物を用いた実験が行わ れてきたが，人体内部の応答を取得できないという問題が あったため, 傷害発生メカニズムを把握することが困難で ある。一方, 近年のコンピュータの性能の向上に伴い, 有 限要素法を用いた傷害解析は盛んに行われてきており，手 指傷害解析にも応用できると考えられる，有限要素法を用 いた傷害解析により指内部の応力分布や变形などの物理量 の調査および様々な条件下での解析が可能となる.

手指有限要素モデルを用いた既存研究の中では皮膚の力 学的応答を解析した研究が多く (3) (6), 傷害に関する研究は ほとんど行われていない。唯一, 勒帯などの軟組織傷害解 析を行っている研究(7)はあるが, 骨折を対象とした研究は 見当たらない.

本研究では, 手指有限要素モデルを構築し, 指はさみに よる骨折傷害を予測できる手指有限要素シミュレーション 手法を開発することを目的とした。

\section{2. 手指有限要素モデルの構築}

日本人男性 1 名の CT 画像より指骨とその周りの軟組織 の外形状を抽出し，ポリゴンモデルを作成した. そして， このポリゴンモデルからサーフェスモデルを作成し, 要素 分割をすることにより手指の有限要素モデルを構築した (Fig.2.1). 要素分割の際には HyperMesh(Altair Engineering 社)を用いた. Fig. 2.2 に構築した手指有限要素モデルを示す. このモデルは末節骨, 中節骨, 基節骨の三つの骨及び, 皮 膚と皮下軟組織から構成されている。ほとんどの部位はソ リッド要素でモデル化されているが, 皮下軟組織モデルの 表面の皮膚モデルはシェル要素を用いた。骨は, 外側の皮 質骨と呼ばれる硬い部分と, 内側の海面骨と呼ばれる網目 状の部分から成り立っており，外側の二層のソリッド要素 は皮質骨とした。また，傷害の対象は指はさみによる骨折 であるため，各関節は両側の軟骨を結合することにより簡 易的に表現した. Table 2.1 は各部位の要素数と節点数を示 している. Table 2.2 に使用した材料特性を示す。これらの 材料特性は先行研究 ${ }^{(3)(8) \sim(12)}$ を参考に設定した.

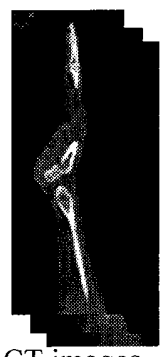

CT images

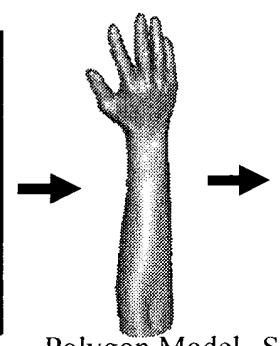

Polygon Model Surface Model
FE Model

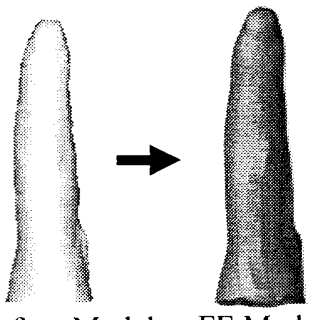

Fig.2.1 Process of developing finger FE model
Table 2.1 Number of nodes and elements of the finger FE model

\begin{tabular}{cccc}
\hline Part & $\begin{array}{c}\text { Element } \\
\text { type }\end{array}$ & $\begin{array}{c}\text { Number of } \\
\text { nodes }\end{array}$ & $\begin{array}{c}\text { Number of } \\
\text { elements }\end{array}$ \\
\hline Distal phalanx & Solid & 1404 & 1056 \\
Medial phalanx & Solid & 1521 & 1152 \\
Proximal phalanx & Solid & 2691 & 2112 \\
Subcutaneous tissue & Solid & 8076 & 5994 \\
Skin & Shell & 2019 & 1998 \\
Cartilage & Solid & 525 & 276 \\
\hline Total & & 16236 & 12588 \\
\hline
\end{tabular}

Table 2.2 Parts and their material properties of the finger FE model

\begin{tabular}{ccccccc}
\hline Part & $\begin{array}{c}\text { Density } \\
{\left[\mathrm{kg} / \mathrm{m}^{3}\right]}\end{array}$ & $\begin{array}{c}\text { Young's } \\
\text { modulus } \\
{[\mathrm{GPa}]}\end{array}$ & $\begin{array}{c}\text { Poisson's } \\
\text { ratio }\end{array}$ & $\begin{array}{c}\text { Yield } \\
\text { strength }\end{array}$ & $\begin{array}{c}\text { Tangent } \\
\text { modulus } \\
{[\mathrm{MPa}]}\end{array}$ & {$[\mathrm{MPa}]$} \\
\hline $\begin{array}{c}\text { Cortical bone } \\
\text { Trabecular } \\
\text { bone }\end{array}$ & 1800 & 17 & 0.3 & 108 & 850 \\
$\begin{array}{c}\text { Subcutaneous } \\
\text { tissue }\end{array}$ & 900 & $3.4 \mathrm{E}-5$ & 0.48 & - & - \\
$\quad \begin{array}{c}\text { Skin } \\
\text { Cartilage }\end{array}$ & 900 & $1.36 \mathrm{E}-4$ & 0.48 & - & - \\
\hline
\end{tabular}

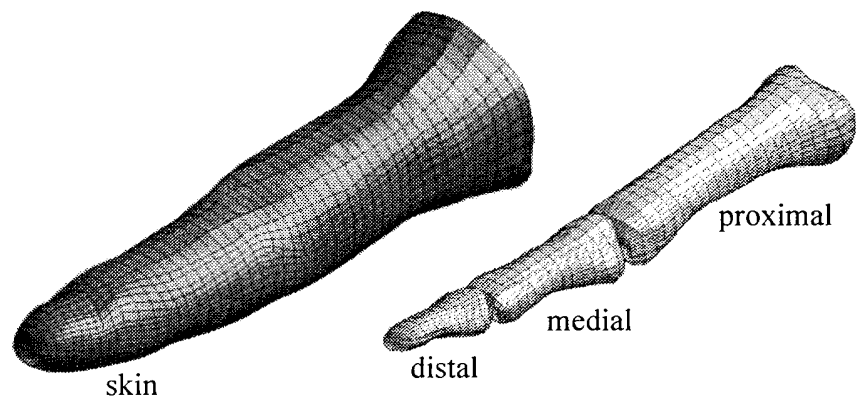

Fig.2.2 Finger FE model

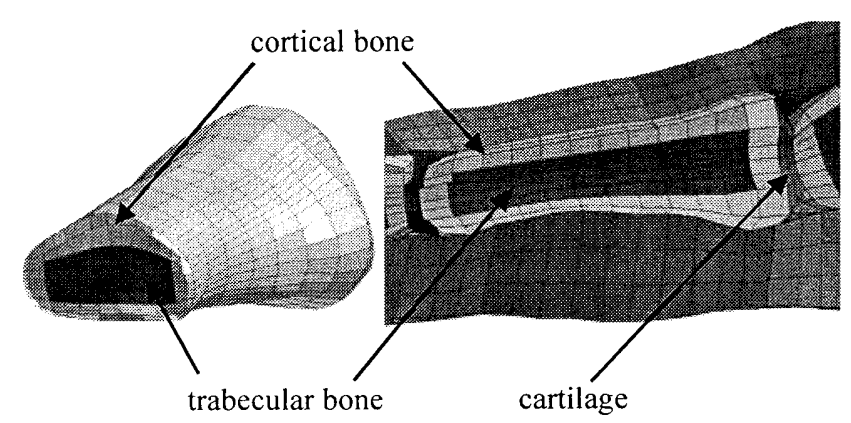

Fig.2.3 Cross sectional view of the finger FE model 


\section{EWK 破壊モデルとパラメータ同定}

\section{1 EWK 破壊モデルの概要}

本研究では骨折を表現するために PAM-CRASH (ESI 社) の EWK 破壊モデル(13)を用いた. EWK 破壊モデルは塑性ひ ずみの蓄積を破壊の評価指標としたモデルであり，様々な 破壊問題において破壊のプロセスを正確に予測することが できたと報告されている(14)。このモデルには, 静水圧引張 によるボイドの成長，非対称ひずみによるボイドの合体お よび臨界体積によるボイドの寸法効果が考慮されている。 $\mathrm{EWK}$ 破壊モデルにおけるダメージの蓄積 $D_{p}$ は以下の式で 表される.

$$
\begin{aligned}
D_{p}= & \int W_{1} W_{2} \partial \bar{\varepsilon}^{-p} \ldots \ldots \ldots \ldots \ldots \ldots \ldots \ldots \ldots \ldots \ldots \ldots \ldots \ldots \ldots \ldots \ldots \ldots \\
& W_{1}=\left(\frac{1}{1+a P}\right)^{\alpha} \\
& W_{2}=(2-A)^{\beta} \\
& a=-\frac{1}{P_{\lim }} \quad A=M A X\left(\frac{S_{2}}{S_{3}}, \frac{S_{2}}{S_{1}}\right) \quad S_{1}>S_{2}>S_{3}
\end{aligned}
$$

ここで, $W_{1}$ は静水圧の重み倸数， $W_{2}$ は非対称ひずみの重 み係数, $\varepsilon^{p}$ は相当塑性ひずみ, $S$ は主偏差応力, $P$ 清静水圧 力である. 臨界体積 $R_{c}$ において, $D_{p}$ が臨界ダメージ $D_{c}$ を超え た時に亀裂が発生することとなる.

先行研究 ${ }^{(14)}$ において $\mathrm{EWK}$ 破壊モデルの $D_{c}, R_{c}, P_{l i m}, \alpha$, $\beta$ の值を変化させることにより, 破壊モードを変化させる ことができることが確認された。これを踏まえて，上記の パラメータの值を変更することにより指骨 (長骨) の骨折 モードを再現できる手指モデルを得ることができると考え られる.

長骨の骨折モードは引張, 圧縮, 曲げ，ねじりの負荷条 件下において Fig.3.1 のとおりである ${ }^{(15)}$. 中節骨モデルの骨 折モードがこれらの骨折モードに一致するようにパラメー タスタディを行い, $D_{c,}, R_{c}, P_{\text {lim }}, \alpha, \beta$ の值を Table 3.1 のよ うに決定した。

Table 3.1 Mechanical properties of bones used for fracture modeling (EWK in Pam-Crash ${ }^{(13)}$ )

\begin{tabular}{ccc}
\hline Material properties & Cortical & Trabecular \\
\hline EWK critical damage $\left(\mathrm{D}_{\mathrm{c}}\right)$ & 1 & 1 \\
EWK critical distance $\left(\mathrm{R}_{\mathrm{c}}\right)$ & 1 & 1 \\
EWK pressure limit $\left(\mathrm{P}_{\text {lim }}, \mathrm{MPa}\right)$ & 259.2 & 15.12 \\
Target failure strain $\left(\varepsilon_{\mathrm{f}}\right)$ & 0.015 & 0.078 \\
EWK pressure exponent $(\alpha)$ & 49.05 & 39.11 \\
EWK asymmetric exponent $(\beta)$ & 33 & 3.68 \\
\hline
\end{tabular}

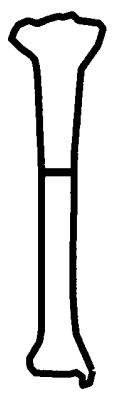

Tension

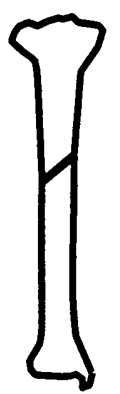

Compression

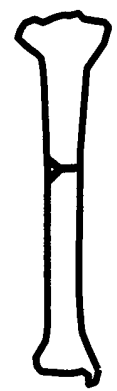

Bending

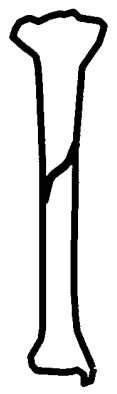

Torsion
Fig.3.1 Fracture modes of long bone

\section{2 EWK 破壊モデルを用いた骨折シミュレーション}

シミュレーションでは, Fig.3.2 のように中節骨モデルの 両端を剛体とし，下端の全自由度を拘束し，上端に変位ま たは回転を与えた。引張および圧縮については一定の速度 $(0.1 \mathrm{~mm} / \mathrm{ms})$ で変位を与えた. ねじりについては一定の角速 度 $(0.03 \mathrm{rad} / \mathrm{ms})$ を与えた。解析ソルバーとして PAM-CRASH を用いた。

曲げシミュレーションでは，Fig3.3 に示すように三点曲 げを行った，支持部およびインパクターを剛体とした。支 持部は直径 $8 \mathrm{~mm}$ の円筒であり，支持間隔は $18 \mathrm{~mm}$ である。 支持部の全自由度を拘束し，インパクターに一定速度 $(0.04 \mathrm{~mm} / \mathrm{ms})$ を図の矢印方向に与えた。

Fig.3.4にシミュレーション結果を示す. 消去された要素 はEWK 破壊モデルの破壊閾値に達した要素である。(a)は 引張のシミュレーション結果である. 亀裂が骨の中央で発 生し, 骨の長軸方向に対して垂直に進展した。この結果は Fig.3.1 に示した骨折モードとよく一致した。(b)は圧縮の シミュレーション結果である。亀裂が最大せん断応力方向 に進展し，報告された骨折モードをよく表現できた。しか し，一部の亀裂が学の長軸方向に対して垂直方向に生じて いる．この原因としては骨の形状により，曲げも同時に発 生したためであると考えられる。(c)はねじりのシミュレー ション結果である，骨の長軸方向に対して斜めおよび同方 向に亀裂が生じ，ねじりによって生じるらせん骨折を表現 できた。

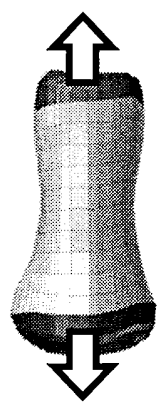

(a)Tension

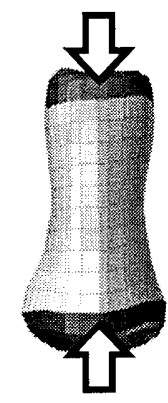

(b)Compression

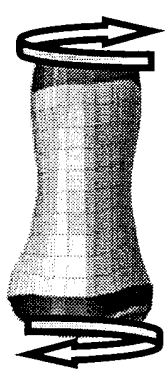

(c)Torsion
Fig.3.2 Simulation conditions of tension, compression and torsion simulation
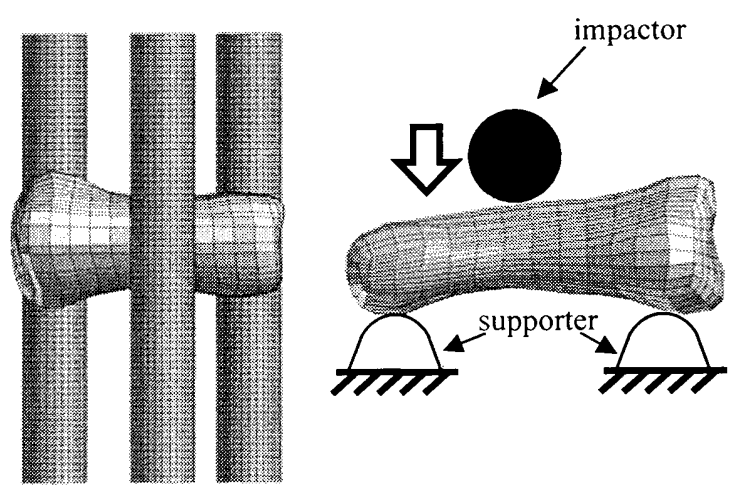

Fig.3.3 Condition of bending simulation 


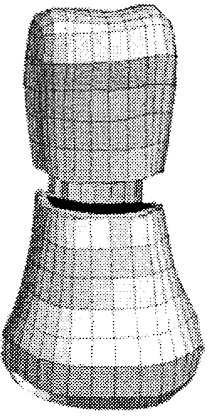

(a)Tension

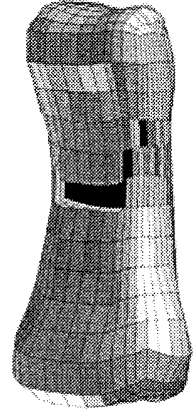

(b)Compression

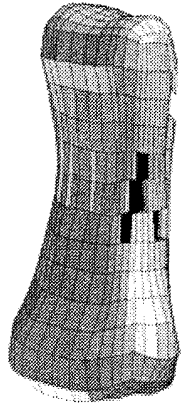

(c)Torsion
Fig.3.4 Simulation results of tension, compression and torsion simulation

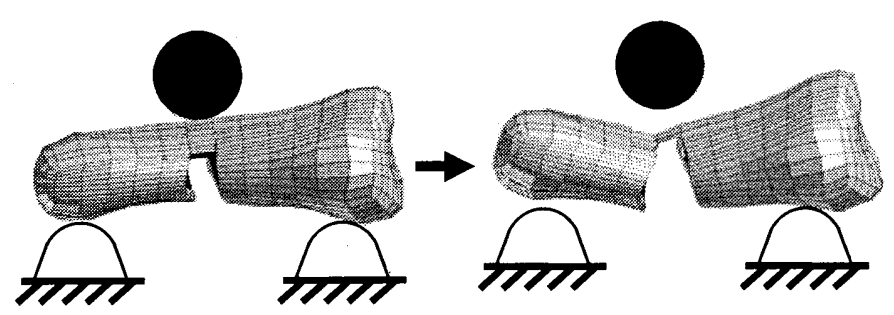

Fig.3.5 Simulation result of bending simulation

Fig.3.4 は曲げ試験のシミュレーション結果である．骨は 圧縮より引張のほうが弱いという特性があるため, 初めは 引張による軸方向に対して垂直方向に進展する亀裂が生じ， その後圧縮による最大せん断応力方向への破壊が発生する. シミュレーションではこのような傾向を表現することがで きた。

以上より，EWK 破壊モデルを用いて様々な負荷条件下 における骨折モードを表現できることを示した。

\section{4. 手指有限要素モデルを用いた重慗シミュレーション}

\section{1 衝撃シミュレーションの概要}

前章で同定した EWK 破壊モデルを用いて Fig4.1 に示す ように指を挟むような衝撃シミュレーションを行った。シ ミュレーションでは，中節骨を含んだ指全部を，固定され た支持部の上に置き, その上からインパクターを衝突させ た。衝撃条件によって骨折モードにどのような変化がある かを調べるために，インパクターと支持部の位置を変化さ せて以下のシミュレーションを行った。

くシミュレーション $(\mathrm{A})\rangle$

インパクターを支持部に向けて背側から掌側へ垂直に衝突

(Fig.4.2(a)) .

<シミュレーション $(\mathrm{B})>$

(A) の条件から支持部を近位方向一 $8 \mathrm{~mm}$ 移動し，インパク ターを背側から掌側へ垂直に衝突(Fig.4.2(b)).

インパクターと支持部はともに剛体の丸棒とした.インパクタ 一には質量 $0.5 \mathrm{~kg}$ と初速度 $3 \mathrm{~m} / \mathrm{s}$ を与之衝突させた. 支持部は 全自由度拘束とし, インパクターは鉛直方向のみ移動可能とし た. また, 指の付け根の要素は全自由度拘束としたことにより, 実際の指はさみ事故の条件に近づけた。

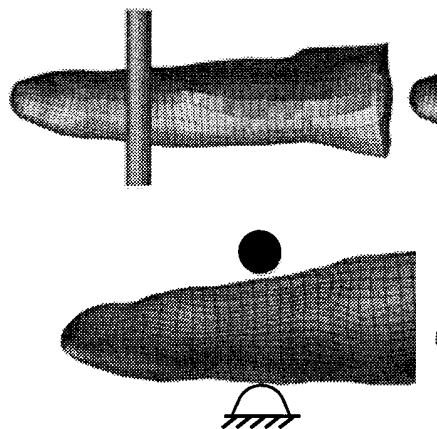

(a) Condition $\mathrm{A}$
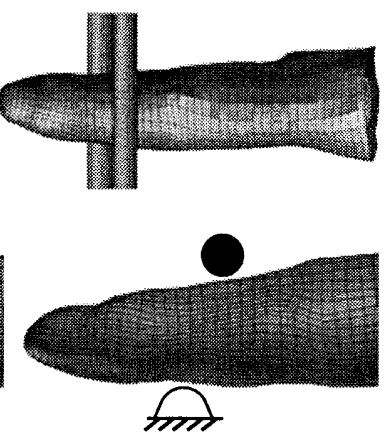

(b) Condition B
Fig.4.1 Simulation condition

\section{2 衝撃シミュレーションの結果と考察}

シミュレーション結果を Fig.4.2 に示し, それぞれの条件につ いて以下に考察する.

くシミュレーション $(\mathrm{A})>$

インパクターと支持部が同一面内にあるシミュレーションでは， インパクターが衝突した箇所の付近の要素が破壞閾値に達し, 粉砕骨折を示した.この衝撃条件では完全骨折が発生しなか った.

くシミュレーション $(\mathrm{B})>$

インパクターの位置をずらしたシミュレーション結果では, 最初 に掌側から破壊が発生し,その後亀裂が背側へ進展していった. これは第 2 章で述べた曲げによる骨折と同様の傾向を示した. また,この衝撃によって完全骨折が発生した.

これらの結果から手指有限要素モデルを用いた衝撃シミュレ 一ションにおいて衝撃条件の違いによって骨折モードが変化 することがわかり，Pierce ら ${ }^{(16)}$ が報告したことと一致している.ま た，同じ運動エネルギーをもったインパクターを衝突させ ても，インパクターと支持部との位置関係によっては骨折 の重症度が異なる可能性のあることがわかった。

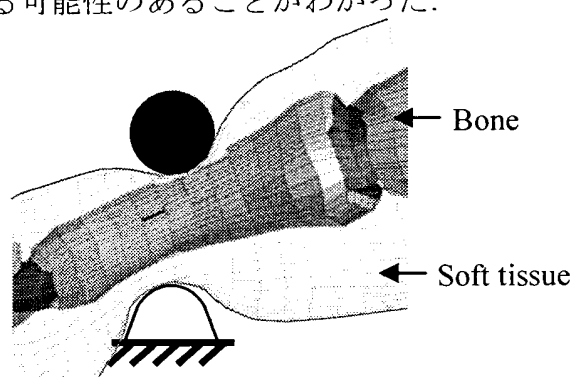

(a) Condition $\mathrm{A}$

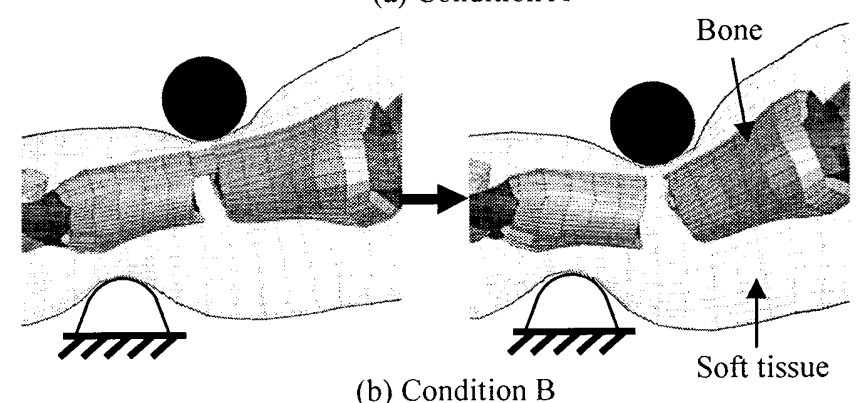

Fig.4.2 Simulation results 
本研究ではPAM-CRASH の EWK 破壊モデルを用いた手 指有限要素モデルにより, 衝撃条件の違いによる骨折モー ドの違いを再現することができた，このようにシミュレー ションにより骨折モードが再現できれば，どのような外力 が作用していたかを知ることができ，指はさみによる骨折 傷害を軽減させる技術・対策の開発に役立つと考えられる。

より正確に骨折を予測するためには，実際の骨を用いた 実験とこれと対応したシミュレーションとを比較すること が必要であるが, 本研究の成果により骨折の定性的な表現 はできたと考えている.

\section{5. 結論}

本研究で得られた成果を以下に述べる.

- 指はさみ事故を解析するために, 日本人成人男性の CT 画像から形状忠実性の高い手指有限要素モデルを構築す ることができた.

- PAM-CRASH のEWK 破壊モデルを用いて, 骨の引張, 圧縮，ねじりおよび曲げシミュレーションを行い，長骨 における骨折モードを再現し，EWK 破壊モデルのパラ メータ同定を行った。

- 取得した EWK 破壊モデルのパラメータ值を手指有限要 素モデルに導入し, 指はさみの衝撃シミュレーションを 行った. その結果, 衝撃条件の違いによって骨折モード が変化し，また骨折の重症度も変化する可能性があるこ とを示した。

\section{参考文献}

（1）松本 浩司，折りたたみ式ベビーカ一の安全性：折りたた み可動部分の安全の考え方を中心に(<特集>子どもの安 全とバイオメカニズム),バイオメカニズム学会誌, Vol. 33, pp. 42-47, 2009

（2）国民生活センター，商品テスト・注意報(国民生活センタ 一) 自動車のドアに挟む事故--ドアに関する事故の分析と スライドドアのテスト，月刊国民生活, Vol. 36(3), pp. 48-54, 2006

(3) Maeno, T., et al., Relationship between the Structure of Human Finger Tissue and Location of Tactile Receptor, JSME international journal. Series C, Mechanical systems, machine elements and manufacturing, Vol. 41,pp. 94-100, 1998
(4) Wagner, M.B., et al., Validation of a 3-D Finite Element Human Fingerpad Model Composed of Anatomically Accurate Tissue Layers, Symposium on Haptic Interfaces for Virtual Environments and Teleoperator Systems 2008, pp. 101-105, 2008

（5）島脇 聡 他, CT 画像から構築した三次元ヒト指部モデル の有限要素法による力学的変形解析, 日本機械学会論 文集 (C 編)，71 巻, 704 号,pp. 204-209, 2005

（6）吉田宏昭 他，三次元有限要素モデルを用いた指先の摩 擦挙動解析, 日本機械学会 第 19 回バイオエンジニアリン グ講演会 講演論文集, pp. 158-159, 2007

（7）沼賀 翼 他，有限要素法による指外傷のシミュレーション， 日本機械学会関東支部ブロック合同講演会 2007 さいたま 講演論文集, pp. 249-250, 2007

(8) Fung, Y.C., Biomechanics: Mechanical Properties of Living Tissues, Springer-Verlag, 1981

(9) Helgason, B., et al., Mathematical relationships between bone density and mechanical properties: A literature review, Clinical Biomechanics, Vol. 23, pp. 135-146, 2008

(10) Wirtz, D.C., et al., Critical evaluation of known bone material properties to realize anisotropic FE-simulation of the proximal femur, Journal of Biomechanics, Vol. 33, pp. 1325-1330, 2000

(11) Bayraktar, H.H., et al., Comparison of the elastic and yield properties of human femoral trabecular and cortical bone tissue, Journal of Biomechanics, Vol. 37, pp. 27-35, 2004

(12) Choi, H.Y., et al., Thorax FE model for older population, ジョイント・シンポジウム 2009 (スポーツエ学シンポジウム) (シンポジウム:ヒューマン・ダイナミクス), pp. 367-372, 2009

(13) VP Solutions: Explicit and implicit solver reference manual, ESI Group, 2008

(14) Kamoulakos, A., The ESI-Wilkins-Kamoulakos (EWK) Rupture Model, Continuum Scale Simulation of Engineering Materials, pp. 795-804, 2005

(15) Paul, G., et al., Finite element modelling of fracture in long bones, International Journal of Crashworthiness, Vol. 4, No.1, pp. 93-110, 1999

(16) Pierce, M.C., et al., Evaluating long bone fractures in children: a biomechanical approach with illustrative cases, Child Abuse \& Neglect, Vol. 28, pp. 505-524, 2004 